\title{
ANALISIS PENGARUH BURNOUT DAN KECERDASAN EMOSIONAL (EI) TERHADAP KINERJA PEGAWAI PT BANK MEGA SYARI'AH \\ CABANG MALANG.
}

\author{
Achmad Sani \\ Jurusan Manajemen Fakultas Ekonomi \\ Universitas Islam Negeri (UIN) Maliki Malang \\ E-mail: achmad_sani79@yahoo.com
}

\begin{abstract}
This research investigates the extent to which Burnout and Emotional Intelligence impacts on the work performance of employee. This research sets its goal to know the significant influence of Burnout and Emotional Intelligence toward the performance of employee Bank Mega Syari'ah Malang. This is explanatory research which has goal o test defined hypothesis on the influence of burnout and Emotional Intelligence toward the work performance of employee. The research population involved 32 employee of Bank Mega Syari'ah Malang. Quistionnaire is used as research instruments in this research. This research employs path analysis to statistically analyze the data in which the coefficient determinants is set on 0,05 level. The result of the research analysis proves that Burnout and Emotional Intelligence simultaneously give significant influence on the work performance employee with determination coefficient shows 0,468. Based on finding, it si further suggested that leader on Bank Mega syar'ah Malang should give more attention to the Burnout and Emotional Intelligence. The result of this research proves that Burnout and Emotional Intelligence simustaneously give significant influence on work performance.
\end{abstract}

Keyword: Burnout, Emotional Intelligence, Work performance.

Perubahan organisasi perusahaan berpengaruh terhadap strategi dan kebijakan manajerial organisasi. Perubahan ini akan menuntut sumberdaya manusia atau pegawai untuk segera menyesuaikan dengan perubahan tersebut. Sumberdaya manusia adalah aset yang sangat vital bagi maju dan berkembangnya organisasi akibat adanya perubahanperubahan yang terjadi. Guna pembenahan organisasi, maka pembinaan secara kontinyu adalah kunci keberhasilan organisasi. Untuk meningkatkan mutu pegawai maka perlu memperbaiki metode dan model pembinaan pegawai, dengan menjamin agar para pegawai dapat melaksanakan tugas secara optimal, tanpa mengalami berbagai gangguan yang dapat mempengaruhi kinerja. Manusia adalah yang menjadi perencana, pelaku, dan penentu dari operasi organisasi, karena itu alat secanggih apapun yang dimiliki organisasi tidak akan mempunyai kegunaan, jika peran aktif sumber daya manusia tidak disertakan. Bertumpu pada sumber daya manusia yang berkualitas tentunya kinerja organisasi dapat ditingkatkan. 
Untuk mewujudkan pelayanan yang optimal maka tidak terlepas dari kinerja pegawai dalam melaksanakan tugasnya. Kinerja pegawai yang baik akan berimplikasi terhadap pelayanan yang baik pula. Program pelatihan adalah salah satu upaya untuk dapat meningkatkan kinerja pegawai dalam menghadapai berbagai macam perubahan baik internala maupun eksternal. Model pelatihan dan metode pelatihan yang tepat dan bervariasi akan mampu mengurangi kebosanan dan kejenuhan pegawai. Sehingga harapan dari model pelatiha ini akan mamapu untuk meningkatkan kapasitas dan kapabilitas pegawai. Sehingga pada akhirnya tujuan perusahaan akan dapat tercapai.

Burnout merupakan tipe khusus ketegangan yang mencerminkan sebuah kepercayaan bahwa beberapa sumber untuk menanggulangi kondisi kondisi yang menekan adalah jarang atau tidak ada, yang menimbulkan seseorang mengalami keputusasaan, keletihan dan kelelahan kognitif (Lee dan Ashforth dalam Alam, 2007). Para peneliti mengkaitkan burnout dengan beragam masalah kesehatan mental dan fisik, keburukan rumah tangga dan hubngan sosial, meningkatnya pergantian dan ketidakhadiran (Perewe et al, 2002).

Pada beberapa dekade terakhir, perasaan emosional di tempat kerja, khususnya emotional intelligence (kecerdasan emosional), menjadi topik perbincangan yang hangat di kalangan manajemen (Ashkanay dan Daus, 2002, dalam Alam (2007). Dalam lingkup pembicaraan itu, dijelaskan melalui Affective Event Theory (AET) atau teori kejadian kejadian afektif (Weiss dan Cropanzano dalam Ashkanay dan Daus, 2002), yang menggambarkan bahwa kepuasan kerja dan loyalitas sebagai suatu sikap kerja, akan membentuk pengendalian perilaku yang terukur, dalam hal (1) keinginan untuk keluar, (2) setuju dan tidak setujunya adanya perilaku sosial, dan (3) bekerja produktif. Sikap kerja sangat dipengaruhi oleh emosi - emosi yang dialami, baik emosi positif dan emosi negatif.

Emotional intelligence mencakup pengendalian diri, semangat, dan ketekunan serta kemampuan untuk memotivasi diri sendiri dan bertahan menghadapi frustasi, kesanggupan untuk mengendalikan dorongan hati dan emosi, tidak melebih - lebihkan kesenangan mengatur suasana hati dan menjaga agar beban stress tidak melumpuhkan kemampuan berpikir, untuk membaca perasaan terdalam orang lain (empati) dan berdoa, untuk memelihara hubungan dengan sebaik - baiknya, kemampuan untuk menyelesaikan konfliks, serta untuk memimpin orang - orang yang dikuasai dorongan hati yang kurang memiliki kendali diri (Cooper dan Sawaf, 2002). 
Penelitian empirik mengenai kecerdasan emosi yang mendasar penelitian ini antara lain : Brown, Briean, dan Reilly (2005), yang meneliti tentang hubungan antara kecerdasan emosional dan hasil yang diharapkan. Tujuan dari penelitian ini adalah untuk meneliti kemungkinan hubungan antara kecerdasan emosional dan hasil yang diinginkan oleh organisasi. Hasil dari penelitian ini adalah mengkonfirmasikan studi sebelumnya mengenai kemampuan efektif dari kepemimpinan transformasional dalam memprediksi kinerja organisasi.

Thomas, Tram, Hara (2005), penelitian tentang hubungan antara kecerdasan emosional dari pegawai, kecerdasan emosional dari manajer, kepuasan kerja pegawai dan kinerja. Hasilnya dengan mengunakan analisis korelasi bahwa kecerdasan emosional dari pegawai berhubungan positif dengan kepuasan dan kinerja. Kecerdasan emosional manager memiliki korelasi yang lebih positif dengan kepuasan kerja. Pegawai yang mempunyai kecerdasan emosional lebih tinggi akan memiliki kepuasan kerja yang tinggi dan kinerja yang tinggi pula.

PT Bank Mega Syari'ah Cabang Malang adalah salah satu Bank Umum Nasional yang berprinsip Syari'ah, mulai berdiri di Malang sejak Tahun 2004 silam. Di Kota Malang telah berdiri beberapa Bank Syariah diantaraya adalah PT Bank Muamalah Indonesia, PT Bank Syari'ah Mandiri, BTN Syari'ah, BRI Syari'ah dan beberapa Bank Prekreditan yang berprinsip syari'ah. Sebagai salah satu Bank Umum Syari'ah di Malang akan dihadapkan pada ragam persaingan, baik dengan sesama bank syariah maupun dengan bank konvensinal yang telah beroperasi lebih dulu. Dengan memperhatikan kondisi obyektif, yaitu persaingan antara bank yang sangat ketat tersebut maka Bank Mega Syariah Cabang Malang harus mampu untuk dapat mengmbil "kue ekonomi" yang masih tersisa.

Berbagai pelatihan telah dilakukan di Bank Mega Syariah guna meningkatkan kinerja para pegawainya. Pelatihan yang telah dilakukan baik berupa pelatihan fisik maupun non fisik (manajerial) dengan harapan agar para pegawai mampu untuk beradaptasi dengan perubahan-perubahan lingkungan dan semakin bersemangat dalam melaksanakan dan menyelesaikan tugas dan tanggungjawabnya. Dengan demikian harapan stake-holder Bank Mega Syariah Cabang Malang agar menjadi salah satu bank syaria'ah terpercaya di mata masyarakat dan sekaligus sebagai market - leader di Malang Raya dapat segera terwujud. Tujuan Penelitian, (1) Untuk menguji dan menganalisis hubungan anttara 
variabel burnout dengan variabel Emotional Intelligence (2) Untuk menguji dan menganalisis hubungan antara variabel Emotional Intelligence dengan variabel kinerja (3) Untuk menguji dan menganalisis hubungan antara variabel burnout dan variabel Emotional Intelligence terhadap variabel kinerja

Brown, Briean, dan Reilly (2005), yang meneliti tentang hubungan antara kecerdasan emosional, kepemimpinan dan hasil yang diharapkan. Tujuan dari penelitian ini adalah untuk meneliti kemungkinan hubungan antara kecerdasan emosional, kepemimpinan dan hasil yang diinginkan oleh organisasi. Responden sebanyak 2.411 pekerja, insinyur dan staf profesional. Studi ini secara empiris meneliti dampak dari kecerdasan emosional seperti yang terukur dengan Bar-Ons Emosional Quotient Inventory (EQI), terhadap hasil yang telah ditetapkan oleh organisasi. Kemampuan kepemimpinan transformasional yang terdokumentasikan untuk memprediksi hasil dan kepemimpinan transformasional. Hasil dari penelitian ini adalah mengkonfirmasikan studi sebelumnya mengenai kemampuan efektif dari kepemimpinan transformasional dalam memprediksi kinerja organisasi. Namun dalam penelitian ini tidak ditemukan dukungan untuk hipotesis mengenai hubungan antara kecerdasan emosional dengan kepemimpinan transformasional.

Sedangkan Thomas, Tram, Hara (2005), Penelitian tentang hubungan antara kecerdasan emosional dari pegawai, kecerdasan emosional dari manajer, kepuasan kerja pegawai dan kinerja dari 187 pegawai jasa-boga Yang bekerja di sembilan restoran yang berbeda yang semuanya tergabung dalam satu jaringan waralaba. Hasilnya dengan mengunakan analisis korelasi bahwa kecerdasan emosional dari pegawai berhubungan positif dengan kepuasan dan kinerja. Kecerdasan emosional manager memiliki korelasi yang lebih positif dengan kepuasan kerja. Pegawai yang mempunyai kecerdasan emosional lebih tinggi akan memiliki kepuasan kerja yang tinggi dan kinerja yang tinggi pula.

Menurut Maslach ( dalam Low et al, 2001) mengatakan bahwa burnout merupakan sindrome psikologis yang terdiri dari tiga dimensi, yaitu (i) adanya kelelahan emosional, (ii) adanya depersonalisasi, (iii) adanya low personal accomplisment. Dijelaskan bahwa pekerjaan yang berorientasi melayani orang lain dapat membentuk hubungan yang asimetrik antara pemberi dan penerima layanan. Seseorang yang bekerja pada bidang pelayanan akan memberikan perhatian, pelayanan, bantuan dan dukungan kepada klien, mahasiswa dan pasien. 
Sementara itu Moore (2000) mengatakan bahwa konsep born-out dapat meliputi antar lain : (1) Konsep Tedium, merupakan sebuah kondisi atau keadaan, fisik, emosi dan kelelahan mental dalam jangka panjang yang disebabkan karena situasi yang terlalu banyak hal negatifnya dibanding hal positifnya. Dalam dikarenakan banyaknya tuntutan tugas dan pemberian penghargaan materi yang tidak sepadan dengan tugas dan tangngjawabnya. (2) Konsep Job Burnout, adalah tekanan emosi yang dialami secara konstan atau berulang - ulang yang diakibatkan karena inetraksi dan konflik dengan orang banyak dalam jangka waktu yang lama.

Sementara itu Moore (2000), menyatakan beberapa penyebab yang mempengaruhi kelelahan kerja (burnout) antara lain : (1) Pekerjaan yang berlebihan, kekurangan sumber daya manusia yang kompeten mengakibatkan menumpuknya pekerjaan yang seharusnya dikerjakan dengan jumlah karyawan yang lebih banyak. (2) Kekurangan waktu, batas waktu yang diberikan untuk menyelesaikan suatu pekerjaan terkadang tidak masuk akal. Pada saat karyawan hendak mendiskusikan masalah tersebut dengan atasannya, si atasan bukannya memberi solusi pemecahan, namuns eringkal memberikan tugas tugas baru yang siap untuk dikerjakan. (3) Konflik peran, konflik peran biasanya terjadi antar karyawan dengan jenjang posisi yang berbeda, yang seringkali disebabkan oleh otoritas yang dimiliki oleh peranan atau jabatan tersebut. (4) Ambiguitas peran, tidak jelasnya deskripsi tugas seringkali membuat karywan mengerjakan sesuatu pekerjaan yang seharusnya tidak dikerjakan oleh karyawan tersebut kalau ditilik dari sisi keahlian maupun posisi pekerjannya.

Jadi dapat disimpulkan bahwa Burnout adalah sebuah tekanan emosi, secara konstan atau berulang - ulang yang diakibatkan karena interaksi dan konflik dengan orang banyak dalam jangka waktu lama. Dan biasanya job burnout ini banyak dialami oleh pekerja public services, seperti perawat, polisi, sosial servise.

\section{Kecerdasan Emosional (Emotional intelligence)}

Definasi yang luas tentang kecerdasan emosional yakni kemampuan untuk memonitor perasaan dan emosi dirinya dan orang lain untuk membedakan antara keduanya, dan menggunakan informasi tersebut untuk mengarahkan pikiran dan tindakan seseorang (Salovey \& Mayer, 1990). Definisi ini menekankan pada sejumlah perbedaan tetapi saling terkait. Kecerdasan emosional itu sendiri dapat dikonsep secara relatif sebagai suatu keasadaran individu terhadap emosinya sendiri dan kemampuan untuk mengekspresikan emosi-emosi tersebut, untuk persepsi-persepsi individual dan kesadaran 
dari emosi-emosi tersebut diekspresikan oleh pihak lain, untuk pengaturan emosi baik untuk diri sendiri atau orang lain, dan untuk menggunakan emosi tersebut.

Solovey (dalam Goleman, 2000), mendefinisikan kecerdasan emosi menjadi 5 (lima) wilayah utama : (1) Mengenali emosi diri (2) Mengelola emosi (3) Memotivasi diri sendiri (4) Mengenali emosi orang lain (5) Membina hubungan. Dari pendapat Golemen dapat disimpulkan bahwa kecerdasan emosional akan memberikan kesadran, yakni kesadra diri atau awareness, yang merupakan kemempuan emosi paling penting untuk melatih swa control. Kecerdasan emosional menjadikan seseorang mampu untuk mengenali diri, berempati, mencintai, berasosiasi dan dapat menyambut kesedihan dan kegembiraan secara lepas.

Komponen yang termasuk dalam variabel kecerdasan emosional ada 7 (Yong, 2003). Tujuh komponen tersebut diukur dengan "The Yong EQ Inventory", yakni kuisioner self-report yang terdiri atas 28 item yang mengukur 7 dimensi dari kecerdasan emosional. Ketujuh dimensi tersebut dipilih berdasarkan studi literatur dari konsep $E Q$ Inventory, misalnya Bar-on dan Parker (2000), Salovey dkk (1995).

Ketujuh dimensi tersebut meliputi : Intrapersonal skills, yakni keahlian seperti kemampuan mengenali emosinya sendiri dan membentuk model diri sendiri yang akurat dan realistik, serta mampu menggunakan model tersebut untuk dioperasikan secara efektif dalam kehidupan. Interpesonal skills, meliputi kemampuan untuk memahami orang lain, apa motivasi mereka, bagaimana mereka bekerja, bagaimana bekerjasama dengan mereka. Assertive, memberikan estimasi terhadap kemampuan terhadap individu untuk mengungkapkan keinginan, pendapat, perasaan dan keyakinan secara langsung, jujur dengan cara-cara yang wajar. Contentment in life, bekerja dengan kepuasan individual dan kebahagian dengan hidup. Reselience, menunjukkan kemampuan individu untuk bangkit dari kekecewaan, belajar dari kegagalan, dan terus maju, gigih dalam menghadapi kesusahan (kemalangan). Self-esteem, menunjukkan perasaan berharga, percaya diri, dan menghormati diri sendiri. Seorang individu dengan self-esteem yang tinggi menganggap memiliki perasaan berharga atas dirinya sendiri. Self-actualization, mengukur prestasi potensial individu, tingkat dimana individu percaya bahwa mereka telah merealisasikan potensinya.

Dalam mencapai tujuan yang telah ditetapkan organisasi dapat melakukan usahausaha dari sumberdaya yang berkualitas. Usaha ini dapat berupa pengembangan, perbaikan sistem kerja, sebagai kelanjutan penilaian terhadap prestasi kerja karyawan. Kinerja diartikan sebagai hasil dari usaha seseorang yang telah dicapainya dengan 
kemampuan yang telah dimilikinya pada kondisi tertentu. Dengan demikian kinerja merupakan hasil keterkaitan antara usaha, kemampuan, dan persepsi tugas yang telah dibebankan (Timpe, 1999). Begitu pula menurut Byars dan Leslie (1995) mengemukakan pengertian kinerja adalah "performance refer to degree of accomplishment of task that make up individual job", yaitu menunjukkan derajat penyelesaian tugas yang menyertai pekerjaan seseorang.

Dalam organisasi pengukuran kinerja digunakan untuk melihat sejauh mana aktivitas yang selama ini dilakukan dengan membandingkan out put atau hasil yang telah dicapai. Untuk melihat kinerja terdapat beberapa perbedaan di antara para ahli untuk mengukurnya. Menurut Dharma (1991) memberikan tolok ukur terhadap kinerja, yaitu: (1) Kuantitas, yaitu jumlah yang harus diselesaikan. (2) Kualitas, yaitu mutu yang dihasilkan.(3) Ketepatan waktu, yaitu kesesuaian dengan waktu yang telah ditetapkan.

Untuk meningkatkan kinerja seorang karyawan diperlukan suatu penilaian kinerja yang disebut dengan performance appraisal. Penilaian kinerja pada umumnya mencakup baik aspek kualitatif maupun kuantitatif dari pelaksanaan pekerjaan. Penilaian kinerja merupakan salah satu fungsi mendasar personalia; yang kadang-kadang disebut juga dengan telaah kinerja, penilaian karyawan, evaluasi kinerja, evaluasi karyawan, atau penentuan peringkat personalia. Semua istilah tersebut berkenaan dengan proses yang sama.

Penilaian kinerja (performance appraisal) secara keseluruhan merupakan proses yang berbeda dari evaluasi pekerjaan (job evaluation). Penilaian kinerja berkenaan dengan seberapa baik seseorang melakukan pekerjaan yang ditugaskan/diberikan. Evaluasi pekerjaan menentukan seberapa tinggi sebuah pekerjaan berharga bagi organisasi dan dengan demikian, pada rentang berapa gaji harus diberikan kepada pekerjaan tersebut (Simamora, 1997)

Sedangkan menurut Stoner dan Wenkel (1986), megemukakan bahwa kinerja adapat diukur melalui kualitas dari pekerjaan dan kuantitas hasil pekerjaan yag telah diselesaikan oleh individu, kelompok atau organisasi. Mathis dan Jackson (2004), mengatakan bahwa terdapat 5 (lima) elemen yang menjadi ukuran kinerja karyawan, yaitu : (1) Kuantitas dari hasil (2) Kualitas dari hasil (3) Ketepatan waktu dari hasil (4) Kehadiran (5) Kemampuan bekerja sama.

Agar variabel tersebut dapat diamati dan diukur, maka perlu dijabarkan lebih lanjut ke dalam model konsep sebagai berikut : 


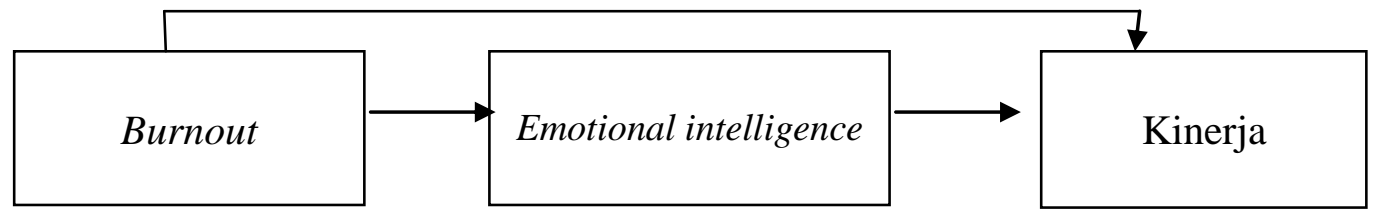

Gambar 1. Kerangka Konseptual yang Menjelaskan hubungan antara Burnout, Emotional intelligence dan Kinerja

Keterangan : $\longrightarrow$ Hubungan

Mengacu pada model hipotesis tersebut, maka rumusan hipotesis yang akan diuji kebenarannya adalah: (1) Diduga ada pengaruh variabel burnout dengan variabel Emotional Intelligence. (2) Diduga ada pengaruh variabel burnout dengan kinerja pegawai. (3) Diduga ada pengaruh variabel Emotional Intelligence dengan variabel kinerja. (4) Diduga ada pengaruh variabel burnout dan variabel Emotional Intelligence dengan variabel kinerja

\section{METODE}

Berdasarkan tujuan penelitian yang telah ditetapkan, maka jenis penelitian ini adalah penelitian eksplanatori. Penelitian eksplanatori (explanatory research) adalah untuk menguji hipotesis antar variabel yang dihipotesiskan. Pada penelitian ini terdapat hipotesis yang akan diuji kebenarannya. Hipotesis itu sendiri menggambarkan hubungan antara dua variabel, untuk mengetahui apakah suatu variabel berasosiasi ataukah tidak dengan variabel lainnya, atau apakah variabel disebabkan atau dipengaruhi atau tidak oleh variabel lainnya (Faisal, 1992).

Teknik pengambilan sampel yang digunakan dalam penelitian ini adalah teknik sampling jenuh, yaitu yaitu teknik pengambilan sampel dimana semua populasi dijadikan sampel. (Sugiyono, 2008). Karena jumlah pegawai di Bank Mega Syariah Cabang Malang seujumlah 32 Orang, maka sampel yang diambil adalah 32 orang pegawai

Tabel 1

Definisi Operasional Variabel

\begin{tabular}{|l|l|l|}
\hline \multicolumn{1}{|c|}{ Konsep } & \multicolumn{1}{|c|}{ Variabel } & \multicolumn{1}{c|}{ Indikator } \\
\hline Burnout & 1. Burnout & 1. Perhatian yang berlebihan terhadap \\
& & pekerjaan \\
& & 2. Perasaan frustasi. \\
& & 3. Bekerja terlalu keras \\
& & 4. Efektifitas penyelesaian kerja \\
& & 5. Kondisi tubuh personal \\
\hline
\end{tabular}




\begin{tabular}{|c|c|c|}
\hline $\begin{array}{l}\text { Emotional } \\
\text { Intelligence } \\
\text { (kecerdasan } \\
\text { emosi) }\end{array}$ & $\begin{array}{l}\text { 1. Emotional } \\
\text { Intelligence } \\
\text { (kecerdasan emosi) }\end{array}$ & $\begin{array}{l}\text { 1. self awareness (kesadaran akan diri } \\
\text { sendiri) } \\
\text { 2. Emotional Resilience (ketangguhan } \\
\text { emosi) } \\
\text { 3. Motivasi } \\
\text { 4. Interpersonality sensitivity } \\
\\
\text { 5. Influence (pengaruh) } \\
\text { 6. Intuitif (intuisi) } \\
\text { 7. Consientiouness (kehati - hatian) } \\
\end{array}$ \\
\hline Kinerja & Kinerja Pegawai & $\begin{array}{ll}\text { 1. } & \text { Kuantitas kerja } \\
\text { 2. } & \text { Kualitas Kerja } \\
\text { 3. } & \text { Ketepatan waktu } \\
\text { 4. } & \text { Pengetahuan tentang pekerjaan }\end{array}$ \\
\hline
\end{tabular}

Untuk menjawab permasalahan disesuaikan dengan model hipotesis, di mana untuk menguji hipotesis penelitian ini digunakan teknik analisis jalur (path analysis). Analisis Jalur (path analysis) diolah dengan paket program komputer, sub- program SPSS (Statistical Program for Social Sciences Windows), sehingga dapat dilakukan estimasi besarnya hubungan kausal antar sejumlah variabel dan hirarkhi kedudukan masingmasing variabel dalam serangkaian jalur-jalur hubungan kausal, baik langsung maupun tidak langsung (Hasan, 1996).

Berdasarkan hasil analisis regresi sederhana variabel bebas terhadap variabel terikat pada Tabel di atas, menunjukkan nilai $\mathrm{p}<0,05$ untuk masing-masing variabel bebas, maka $\mathrm{H}_{0}$ ditolak. Hal ini berarti variabel Burnout dan variabel Emotional Intelligence secara sederhana mempunyai pengaruh yang signifikan terhadap prestasi kerja pegawai. Dengan demikian hipotesis (1), (2), (3) dan (4), yang menyatakan ada pengaruh yang signifikan burnout, emotional Intelligence terhadap kinerja pegawai dapat diterima, baik secara sederhana maupun secara berganda. Berdasarkan hasil analisis regresi linier, maka dapat dihasilkan persamaan regresi sebagai berikut :

$\mathrm{Y}=19,170+0,548 \mathrm{X}_{1}+0,339 \mathrm{X}_{2}+\varepsilon$

Dalam melakukan pembuktian terhadap hipotesis yang diajukan dilakukan dengan teknik analisis jalur (path analisis) dengan menggunakan bantuan program SPSS 16. Analisis jalur adalah untuk mengetahui pengaruh langsung dan tidak langsung dari variabel yang diteliti. Untuk menguji analisis jalur diperlukan identifikasi koefisien jalur pada tiap - tiap tahap sebagai berikut : Tahap satu. Uji 
jalur P1. Pada jalur P1, koefisien beta pada variabel burnout (X1) sebesar 0,929. Hal ini menunjukkan bahwa variabel burnout mempunyai dampak terhadap variabel emotional Intelligence. Berdasarkan uji t, variabel burnout memberikan pengaruh yang signifikan terhadap variabel emotional Intelligence, dengan nilai t sebesar 1,222; dengan nilai signifikansi 0,026 yang lebih kecil dari 0,05. Dengan demikian Ho ditolak, yang artinya ada pengaruh yang signifikan antara burnout dengan emotional Intelligence dapat diterima dan terbukti kebenarannya.

Tahap 2. Uji jalur P2. Pada jalur P2, koefisien beta pada variabel burnout (X1) sebesar 0,753. Hal ini menunjukkan bahwa variabel burnout mempunyai dampak terhadap variabel kinerja pegawai. Berdasarkan uji t, variabel burnout memberikan pengaruh yang signifikan terhadap variabel kinerja pegawai, dengan nilai t sebesar 1,917; dengan nilai signifikansi 0,035 yang lebih kecil dari 0,05. Dengan demikian Ho ditolak, yang artinya ada pengaruh yang signifikan antara burnout dengan kinerja pegawai dapat diterima dan terbukti kebenarannya.

Tahap 3. Uji jalur P3. Pada jalur P3, koefisien beta pada variabel emotional Intelligence (X2) sebesar 0,943. Hal ini menunjukkan bahwa variabel emotional Intelligence mempunyai dampak terhadap variabel kinerja pegawai. Berdasarkan uji t, variabel emotional Intelligence memberikan pengaruh yang signifikan terhadap variabel kinerja pegawai, dengan nilai t sebesar 1,714; dengan nilai signifikansi 0,045 yang lebih kecil dari 0,05 . Dengan demikian Ho ditolak, yang artinya ada pengaruh yang signifikan antara emotional Intelligence dengan kinerja pegawai dapat diterima dan terbukti kebenarannya.

Tahap empat. Uji Jalur P4. Pada jalur P4, koefisien beta pada variabel burnout $\left(\mathrm{X}_{1}\right)$ sebesar 0,548 dan koefisien beta variabel emotional Intelligence $\left(\mathrm{X}_{2}\right)$ sebesar 0,339. Hal ini menunjukkan bahwa variabel burnout $\left(\mathrm{X}_{1}\right)$ dan variabel emotional Intelligence $\left(\mathrm{X}_{2}\right)$ mempunyai dampak pada kinerja paegawai Bank Syari'ah Cabang Malang.

Berdasarkan uji $\mathrm{F}$, variabel burnout $\left(\mathrm{X}_{1}\right)$ dan variabel emotional Intelligence $\left(\mathrm{X}_{2}\right)$ mempunyai pengaruh terhadap variabel kinerja pegawai dengan nilai $\mathrm{F}$ sebesar 22,559 dengan angka probabilitas sebesar 0,046 lebih kecil dari 0,05, maka $\mathrm{H}_{0}$ Ditolak. Hal ini berarti berdasarkan hasil penelitian menunjukkan bahwa burnout dan emotional Inteligence mempunyai pengaruh yang signifikan terhadap kinerja pegawai, dapat diterima dan terbukti kebenarannya. 
Gambar 3. Hasil Analisis Jalur

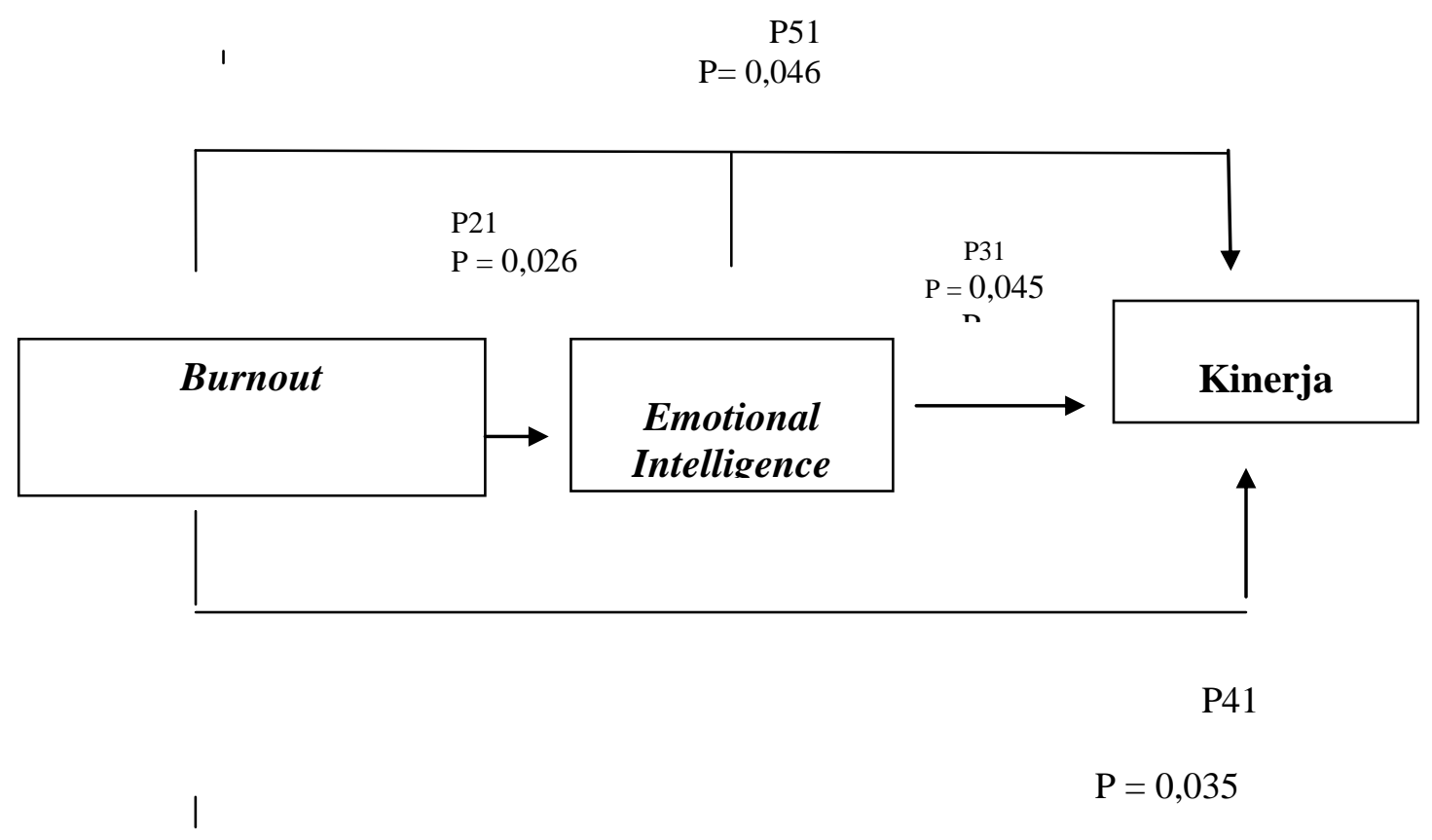

\section{HASIL DAN PEMBAHASAN}

Berdasarkan hasil penelitian di lapangan menunjukkan bahwa variabelvariabel Burnout dan Emotional Intelligence secara simultan mempunyai pengaruh yang signifikan terhadap kinerja pegawai $(\mathrm{p}=0,046<0,05)$. Variasi perubahan nilai variabel kinerja pegawai yang dapat dijelaskan oleh seluruh variabel bebas secara simultan sebesar $46,8 \%$, selebihnya dijelaskan oleh variabel lain.

Hasil tersebut sejalan dengan adanya temuan bahwa pada dasarnya burnout dan emotional Intelligence berhubungan dengan kepuasan kerja dan kinerja. Diprediksi dan ditemukan bahwa Burnout berkorelasi negatif dengan kinerja, sedangkan emotional Intelligence berkorelasi positif dengan kepuasan kerja dan kinerja. (Tram, O’ Hara, 2006). Kemudian hasil pengujian secara sederhana terhadap variabel bebas, dapat diketahui bahwa Burnout mempunyai pengaruh yang signifikan terhadap kinerja pegawai. Hal ini dapat dibuktikan dari tingkat signifikansi t variabel $(0,035)<(0,05)$. Pada penelitian ini, variabel Burnout ditunjukkan oleh kelelahan emosi dan berkurangnya pestasi personal. Hasil penelitian di lapangan mendukung teori yang dikemukakan (Pines dalam Alam, 2007), pada dasarnya burnout 
didefinisikan sebagai kehabisan tenaga secara fisik (depletion), perasaan tidak berdaya dan putus asa, kelelahan emosional (emotional drain) dan munculnya konsep diri yang negatif terhadap pekerjaan, prestasi, kehidupan dan terhadap orang lain"

Kemudian hasil pengujian secara sederhana terhadap masing-masing variabel bebas, dapat diketahui bahwa emotional Intelligence mempunyai pengaruh yang signifikan terhadap kinerja pegawai. Hal ini dapat dibuktikan dari tingkat signifikansi t variabel $(0,045)<(0,05)$. Pada penelitian ini, variabel emotional Intelligence ditunjukkan dengan adanya kesadaran diri sendiri, ketangguhan emosi, motivasi, kepekaan interpersonal, pengaruh, intuisi, dan kehati - hatian.

Secara teoritis hasil penelitian tersebut mendukung pemikiran Cherniss, 2000), yang menyatakan bahwa kompetensi emotional merupakan dasar emotional Intelligence. Suatu tingkatan dalam emotional Intelligence perlu mempelajari kompetensi emosional. Misalnya kemampuan untuk mengakui secara akurat apa yang dirasakan orang lain memungkinkan seseorang mengembangkan kompetensi spesifik yang disebut sebagai pengaruh. Sedangkan orang yang bisa mengatur emosi dengan baik akan lebih mudah mengembangkan kompetensi inisiatif atau dorongan berprestasi.

Hal senada diungkapkan oleh Cooper dan Sawaf (2002), bahwa pada dasarnya manfaat - manfaat yang dihasilkan emotional intelligence merupakan faktor keberhasilan organisasi adalah berkaitan dengan pembuatan keputusan, kepemimpinan, terobosan teknis, komunikasi terbuka dan jujur, bekerjasama dan saling mempengaruhi, membangun loyalitas, kreatifitas, inovasi yang pada akhirnya akan berpengaruh pada prestasi.

\section{Kesimpulan dan Saran}

\section{Kesimpulan}

Berdasarkan hasil analisis data dan pembahasan yang telah dilakukan, maka dapat ditarik kesimpulan sebagai berikut; Hasil analisis deskriptif secara umum menunjukkan bahwa rata - rata pegawai Bank Mega Syari'ah pernah merasakan dan mengalami burnout. Hal ini dapat diketahui dari rata - rata jawaban responden, yang memberikan jawaban kuesioner tentang burnout. Sedangkan untuk emotional Intelligence, rata - tara jawaban responden sudah baik. Demikian juga hasil penilaian kinerja, secara umum menunjukkan bahwa pegawai mempunyai kinerja yang baik. Burnout dan Emotional Intelligence secara simultan mempunyai pengaruh yang 
signifikan terhadap kinerja pegawai, dengan $\mathrm{R}^{2}$ disesuaikan sebesar 0,468 artinya variasi perubahan nilai variabel kinerja pegawai yang dapat dijelaskan oleh seluruh variabel bebas (Burnout dan Emotional Intelligence) sebesar 46,8\%.

Burnout mempunyai pengaruh yang signifikan terhadap Emotional Intelligence, dengan nilai $\mathrm{t}$ hitung 1,222, dengan signifikansi $\mathrm{t}$ sebesar $0,026<(0,05)$. Burnout mempunyai pengaruh yang signifikan terhadap kinerja pegawai, dengan nilai $\mathrm{t}$ hitung 1,917 , dengan signifikansi t sebesar $0,035<(0,05)$. Emotional Intelligence mempunyai pengaruh yang signifikan terhadap kinerja pegawai, dengan nilai t hitung 1,714, dengan signifikansi t sebesar $0,045<(0,05)$. Berdasarkan hasil penelitian yang telah dilakukan, menunjukkan bahwa Burnout dan Emotional Intelligence terhadap Kinerja Pegawai Bank Mega Syari'ah cabang Malang.

\section{Saran}

Berdasarkan kesimpulan di atas, saran yang dapat diberikan antara lain; Untuk menghindari terjadinya burnout yang dialami oleh setiap pegawai, hendaknya pimpinan bank selalu melakukan pemberdayaan kepada pegawai. Karena pada dasarnya pemberdayaan adalah proses motivasional dimana seorang individu merasakan dirinya menjadi lebih mampu (enablement). Untuk suksesnya pencapaian tujuan organisasi, maka hendaknya perumusan tujuan organisasi melibatkan individu - individu atau kelompok atau semua unsur dalam suatu organisasi. Demikian juga dalam hal pembebanan tugas. Tugas hendaknya tidak hanya dibebankan kepada satu orang saja. Sehingga individu individu, kelompok - kelompok, semua unsur merasa bertanggung jawab atas penyelesaian pekerjaan yang nantinya akan berdampak pada pencapaian tujuan organisasi sebagai pencapaian bersama, dan bukan hanya pencapaian seseorang. Dengan demikian perasaan jenuh kerja (burnout) yang dirasakan hampir setiap pegawai dapat dikurangi.Rata - rata pegawai Bank Mega Syari'ah mempunyai Emotional Intelligence yang sudah baik. Dengan EI yang tinggi diharapkan semua pegawai benar - benar mau mengerti dan perhatian terhadap apa yang diinginkan oleh para pemakai jasa (customer Bank Mega Syari'ah).

Disarankan pula untuk dilakukan penelitian terhadap variabel-variabel lain yang dapat mempengaruhi kinerja pegawai serta kondisi-kondisi yang mempengaruhinya. beberapa aspek yang belum tercakup dalam penelitian ini adalah : penggunaan kekuasaan, karakteristik pekerjaan, kemampuan dan motivasi. Demikian juga melakukan 
penelitian korelasi timbal balik antara burnout dan kinerja pegawai, serta penelitian tentang penyebab timbulnya burnout, hubungan empowerment dengan burnout, dan sebagainya.

\section{DAFTAR PUSTAKA}

Arikunto, Suharsimi.1991. Prosedur Penelitian, Suatu Pendekatan Praktis. Penerbit Rineka Cipta. Jakarta. 
Bernardin, H John \& Russell, Joyce E.A. 1993. Human Resources Management. McGraw Hill. New York.

Bhanugopan, Ramadu dan Alan Fish. 2006. An empirical Investigation Of Job Burnout Amoung Expatriates. Personal Review, Vol 35. No. 4 pp 449- 468. Emerald Group Publihing Limited.

Benson, S.P.G Truskett, B. Findlay. 2007. The Relationship between Burnout and emotional Intelligence In Australian Surgeon and Surgical Trainees. ANZ Journal Of Surgery, Oxford : May 2007. Vol 77, Iss.sl;pg A79

Brown, Williem. Bryant, Scott. \& Reilly, Michael. 2006. Does Emotional Intellegence As Measured By The EQI, Influence Transformation Leadership and Desirable Outcomes. Leadership and Organization Development Journal. Vol. 27, No. 5, Tahun 2006, pp. 330-352

Byars, Lloyd .L \& Leslie W. Rue. 1995. Human Resources And Personal Management. Richard D Irwin. Inc, Illionis. USA.

Bycio, Peter, Joyce S Allen and Rick D Hacket. 1995. Further Assesment of Bass's (1985): Conceptualization on Transactional and Transformational Leadership. Journal of Applied Psychology (Vol. 80, No.4), p.468-478

Coper K Robert \& Sawaf Ayman. 2002. Executive EQ, Kecerdasan Emosional Dalam Kepemimpinan dan Organisasi, Alih bahasa Alex Tri Kontjoro, Penerbit PT Gramedia Pustaka Utama, Jakarta

Dessler, G. 1993. Personnal Management : Manajemen Personalia, Terjemahan Agus Dharma, Penerbit Erlangga, Jakarta

Downey, L.A \& Papageorgiou \& Stough. 2006. Examining The Relationship Between Leadership, Emotional Intelegence \& Instuition In Senior Famele Manager In Australia, Leadrship and Organization Journal, Vol. 27, No. 4,Tahun 2006, pp. 250-264

Djarwanto, P.S \& Subagyo, P. 1993. Statistik Induktif. Edisi IV. BPFE. Yogyakarta.

Faisal, Sanapiah. 1992. Format-Format Penelitian Sosial. Penerbit Rajawali. Jakarta

Golemen, D. 1995. Emotional Intellegence : Why can matter more than IQ. NY. Bantam Book

Golemen, Daniel. 2000. Emotional Intellegent : Kecerdasan Emosional, Mengapa EI lebih penting dari IQ, Penerbit Gramedia Pustaka Utama, Jakarta, Cetakan ke sepuluh.

Hapsari, Elsi Dwi. 2006. Menyiapkan Perawat Yang siap Berkompetensi Di Era pasar global. Jurnal Inovasi Vol 6. XVIII/ Maret 2006.

Henry R Meyer. 2007. Manajemen Dengan Kecerdasan Emosional, Penerbit PT Nuansa Bandung

Mathis C Robert \& Jackson H John. 2006.; Human Resources Management : Manajemen Sumber Daya Manusia, Terjemahan Diana Angelica, Penerbit Salemba Empat, Jakarta

Meyer, J.D \& Salovey, P. 1997. What is emotional intellegence ?. NY. Basic Book

Perrewe, L. Pamela,. Wayne A. Hochwarter, Ana maria Rossi, Allan Wallace,......2002. Are Work stress Relationships Universal ? A nine region Examination Of Role stressors, General Self Efficacy and Burnout. Journal of International management 8. 163 - 187. Elsevier Science Inc.

Rivai, Veithzal. 2004. Manajemen Sumberdaya Manusia Untuk Perusahaan : Dari Teori ke Praktek. Penerbit Raja Grafindo Persada, Jakarta

R. Alam. 2007. Empowerment hubungannya dengan burnout paramedis rumah sakit rujukan. Disertasi. Tidak dipublikasikan. 
Ruki, Achmad. 2001. Performance Management System: Sistem Manajemen Kinerja. Penerbit PT Gramedia Pustaka Utama, Jakarta

Sojka. Jane Z and Dawn R Deeter. 2002. Enhancing The Emotional Intellegence Of Salespeople. Journal of Bussiness : Spring 17.1

Stoner, James and Wenkel, C. 1986. Management, terjemahan Agus Maulana dkk, Penerbit Erlangga, Jakarta, Jilid 2.

Sugiyono. 2008. Metode Penelitian Bisnis. Penerbit Alfabeta. Bandung.

Sulistani D Ratna, Mehdi M. 2006. Emosional Intellegent. Penerbit PT Gramedia Pustaka Utama, Jakarta, Cetakan Pertama.

Swasto, Bambang. 1996. Manajemen Sumber Daya Manusia. Fakultas Ilmu Administrasi. Universitas Brawijaya. Malang.

Thomas Sy, Susanna Tram, Linda A.O'Hara. 2006. Relation of Employee and Manager Emotional Intellegence To Job Satisfaction And Performance. Journal of Vocational Behaviour 68, p.461-473

Viriyavidhayavong and Jiamsuchong, Satita. 2005. The Relationship Between Emotional Quotient And Leadership Effectiveness In Life Insurance Bussiness Organizations. Journal Of Managerial Psychology, Vol. 8, No 10, p.22-34 
